ORCID ID: https://orcid.org/0000-0002-0273-8469

Сичова А. О., Луганський національний університет імені Тараса Шевченка

\title{
КОЛАБОРАЦЙНІ ПЛАТФОРМИ ЯК ІНСТРУМЕНТ ГЛОБАЛЬНОї ПОЛІТИКИ
}

\begin{abstract}
У статті подано аналіз категорії колабораційної платформи у контексті становлення глобального політичного партнерства. Під колаборачійними платформами розуміються відносно стабільні структури для забезпечення більш гнучкого режиму управління, здатного адаптуватися до нових можливостей або мінливих умов. Автором ідентифіковані властивості колабораційних платформ, а саме: гнучкість, відносна часова стабільність, реконфігурачія, модульність та еволюиійність, щзо дозволяє відрізнити платформи від інших інструментів фасилітації співробітниитва. Комбінація організаційних аспектів і структурних елементів колабораційних платформ надає змогу підключитися до модульних інституціональних інтерфейсів, сконфігурованих з урахуванням локальних потреб і умов, усім зацікавленим сторонам. Окрему увагу було сфокусовано на ефектах позитивного зворотного зв'язку та синергізмі зусиль стейкголдерів з метою полегшення координачї̈ дій та створення своєрідної екосистеми політичних суб 'єктів $і$ процесів. У статті також представлена типологія та приклади колаборачійних платформ залежно від домінуючих иілей співпрачі та вузлів взаємозалежності, які свідчать про функиіональну варіативність платформ у контексті забезпечення спільного вирімення проблемних ситуацій. Окремим блоком було ідентифіковано низку проблем, які супроводжують дослідження колабораційних платформ. Серед них особливу увагу було зосереджено на суперечності критеріїв ефективності співпраці, ступенях потениійного контролю та проблемах міжсекторального партнерства. Авторкою також окреслені перспективи подальшого вивчення колабораційних платформ як механізмів адаптивного управління, а саме: урахування мікроелементів співробітництва та інституційної динаміки платформ, визначення алгоритмів моделювання та впливу платформ на стабільність політичної системи у цілому.
\end{abstract}

Ключові слова: колабораційна платформа, колаборація, колабораџійне управління, партнерство, посередництво

Постановка проблеми. Колабораційне управління все частіше розглядається як проактивний інструмент політики, що дозволяє екстраполювати стратегію співпраці з поточного контексту на міжнародний рівень. Якщо в минулому уряди, місцеві спільноти та НУО зверталися до практики колаборації як до останнього засобу у випадку провалу односторонніх стратегій, то сьогодні чимало інституцій, наприклад, World Vision International, прописують формування колабораційних інструментів в якості обов'язкового пункту на порядку денному.

Класичні конференції, партнерства і політичні мережі поступово замінюються новою категорією - колабораційна платформа. Остання набула популярності завдяки успішним технологічним інструментам на кшталт Apple iPhone, а також інноваціям з відкритим вихідним кодом (open source innovation) або краудсорсингу. 3 IT-сфери термін «платформа» поступово переходить до політичного простору, що демонструють, наприклад, Європейська платформа боротьби з бідністю та соціальною ізоляцією або Платформа управління FramingNano. Проте залишається відкритим питання: чим власне виступає колабораційна платформа - даниною моді чи новим кроком у логіці державного управління?

Приватизація і передача низки державних функцій на аутсорсинг у зв'язку з появою концепції нового публічного менеджменту, а також активність НУО, призвели до вибуху партнерств між державними структурами, бізнесом і громадянським сектором. Ідеї колабораційного управління посилюються за рахунок розуміння обмеженості традиційних галузевих рішень і необхідності їх посилення логікою запозичення з інших секторів управління.

Колабораційні платформи вже визнані успішною стратегією вирішення проблем у таких питаннях, як надання гуманітарної допомоги [19], сільськогосподарські інновації [18], регіональна

(C) Сичова А. О., 2021 
економіка [6] і сталий розвиток [20]. Займаючи особливу нішу в системі управління, платформи спрямовані на фасилітацію та регулювання відносин співробітництва між максимальною кількістю стейкголдерів. Аналогічно багатосторонній ринковій платформі Uber, колабораційна платформа здатна зіграти роль своєрідного «мета-простору» в політиці, об'єднавши усі зацікавлені сторони у спільному прагненні знайти вирішення локальної або глобальної проблеми.

Mema cmammi полягає у спробах прояснити концепцію колабораційної платформи, освітивши їі відмінні риси та властивості в контексті колабораційного управління, а також простежити логіку формування колабораційних платформ як інструменту стимулювання співпраці між зацікавленими сторонами. Для внесення конкретики і ясності в категорію платформи слід чітко усвідомлювати синонімічні їй явища та критерії виявлення потенційних відмінностей, що дозволить адаптувати розроблений теоретичний фундамент стосовно платформ до сфери управління.

Незважаючи на пул академічних робіт щодо співпраці за участю зацікавлених сторін, у політологічній літературі платформи в якості механізмів каталізації спільного управління практично не згадуються. Проте концепція архітектури віртуальних платформ привела дослідників до необхідності поступової переорієнтації на колабораційні платформи як стратегію створення електронного уряду [23].

Теоретики організаційного підходу розуміють під колабораційними платформами «організації або програми зі спеціальними компетенціями і ресурсами з метою створення загального фундаменту для проведення поточних спільних проєктів» [13, с.3]. Важливим винятком серед наукових робіт, присвячених виключно аналізу платформ співпраці, слугує стаття С. Намбісана [17]. Використовуючи критерій функціональності, вчений розрізняє три типи платформ, а саме: дослідницькі платформи для формулювання спільного бачення проблеми; експериментальні платформи з метою вивчення та попередньої оцінки можливих рішень і сценаріїв розвитку подій і платформи реалізації, що сприяють застосуванню спільних зусиль для імплементації розроблених рішень.

К. Сіборра одним з перших проаналізував бізнес-структури як потенційні колабораційні платформи на прикладі стратегії італійської фірми Olivetti. На його думку, платформа виступає «... тим контекстом, який формує інституції та процедури вирішення проблем за допомогою відомих форм, таких як ієрархія, матриця або мережа, але на досить гнучкій основі» [5, с.103]. Суть концепції платформи, розробленої К. Сіборра, полягає в ідеї, згідно з якою платформи створюють стабільну структуру для забезпечення більш гнучкого режиму управління, який з часом адаптується до нових можливостей або мінливих умов. Відповідно, колабораційні платформи можуть виконувати роль стратегії адаптивного управління, формуючи або реорганізовуючи проєкти 3 появою додаткових ресурсів або проблем.

Виклад основного матеріалу. Концепція платформи істотно доповнює ідею режимів колабораційного управління, розроблену К. Емерсоном і Т. Набатчі. За їх визначенням, режим колабораційного управління представляє собою «систему, в умовах якої транскордонне співробітництво $€$ переважаючим способом поведінки, прийняття рішень і діяльності між автономними учасниками, об’єднаними заради досягнення колективної мети» [9, с.18]. У зазначеному контексті платформу можна розглядати як ключовий компонент незалежно створеного або керованого ззовні режиму. Однак якщо типологія режиму враховує перспективу співпраці, концепція платформи фокусується саме на організації процесу співробітництва між зацікавленими сторонами.

К. Емерсон і Т. Набатчі справедливо відзначають, що обов'язкові або встановлені заздалегідь форми співпраці з огляду на наявність зовнішнього тиску не завжди супроводжуються практиками колабораційного управління [9, с.174-175]. Проте концепція колабораційної платформи здатна привернути увагу до впливу початкових умов на можливість застосування механізму співпраці. Якщо ідея режиму передбачає комплексний і стійкий характер спільного управління, то концепція платформи фокусується на вузькоспеціалізованому завданні щодо спрощення та адаптивного управління сукупністю спільних проєктів або мереж.

Хоча визначення колабораційних платформ, перш за все, підкреслює організаційні аспекти, маючи на меті відрізнити їх від самого механізму співпраці, на практиці зазначені поняття часто сприймаються як синонімічні. 3 одного боку, платформи полегшують встановлення співпраці, у той час як сама співпраця може здатися простим розширенням платформи. Навіть там, де існує більш чітке розмежування між організацією платформи і пов'язаними з нею взаємодіями, елементи платформи можуть виявитися органічно вбудованими у взаємодії, які вона, своєю чергою, допомагає організувати. 
Визначення К. Сіборра дозволяе виділити кілька характеристик колабораційних платформ. По-перше, вони забезпечують фундамент, за допомогою якого можуть бути організовані інші різновиди спільної діяльності. По-друге, структура платформ відносно стабільна в часі, проте дії, які виконується за іiі посередництвом, можна реорганізувати і підкорегувати. По-третє, платформа виступає не просто пасивною опорною конструкцією, але полегшує реконфігурацію процесів. Отже, платформи створюють простір для фасилітації взаємодії стейкголдерів через обмін інформацією та ресурсами, створюючи стандартизовані технологічні інтерфейси або комунікаційні форуми.

Однією 3 характерних властивостей колабораційних платформ виступає модульність, яка дозволяє досягти координації дій між зацікавленими сторонами і «одночасно зменшити ступінь управлінського контролю» $[10$, с.791]. Оскільки тактика колабораційних платформ зазвичай передбачає добровільну участь незалежних або автономних суб'єктів, вони рідко володіють достатньою владою над стейкголдерами для здійснення безпосереднього контролю над процесом взаємодії. Певною мірою управління платформою є екологічним, що досягається шляхом розробки інституціональної структури співпраці і постає непрямим наслідком спільної діяльності.

Такій узгодженості сприяють єдині правила проєктування, стандартизовані інтерфейси співпраці і протоколи зв'язку. Комбінація модульності та реконфігурованості створює потенціал для формування колабораційних екосистем політичних процесів і суб'єктів. Проте ключовою проблемою дизайну, пов'язаного з посередництвом, контролем і продуктивністю, постає відносна відкритість платформи.

Платформи часто асоціюються з відкритими інноваціями, які дозволяють учасникам вільно отримувати доступ до основних ресурсів та інфраструктури задля досягнення власних цілей. К. Будро пропонує два різні способи доступу до платформи [3, с.1855]. Перший надає відкритий доступ до платформи, але контроль залишається за ії ініціаторами, другий - передає певну ступінь контролю над платформою обмеженій кількості зацікавлених осіб.

3 одного боку, відкритість платформ надає певні переваги, які можна побачити на прикладі краудсорсингу. Так, С. Рос [21] описує дві регіональні краудсорсингові платформи з різним ступенем відкритості. Одна з них дозволяє подавати ідеї лише тим, хто знаходиться у межах регіону, а інша $\epsilon$ відкритою для пропозицій з інших локацій. Згідно з С. Росом, більша відкритість підвищує ймовірність виходу з так званого «регіонального блокування». 3 іншого боку, платформи можуть прагнути до закритості через посилення контролю з позиції діючих зацікавлених сторін, котрі прагнуть впевненості в очікуваннях відносно правильності вкладених інвестицій. Більша відкритість платформ тягне за собою збільшення ризиків, що може підірвати бажання стейкголдерів інвестувати у платформу.

Як зазначають М. Янссен і Е. Естевес, «ідея платформи полягає в тому, щоб створити спільноту однодумців i, тим самим, знизити транзакційні витрати, надавши певний рівень контролю користувачам» $[13$, c.5]. Але в цьому і криється проблема. Посилаючись на платформи електронного уряду, дослідники визнають, що «жорсткий контроль може налякати учасників колаборації, тоді як занадто демократичний контроль може призвести до анархії» [13, с.6]. Відповідно, надмірний контролінг здатний підірвати легітимність переговорного процесу, перешкодити появі актуальних ідей та обмежити можливості для синергізму зусиль стейкголдерів.

Еволюційність також виступає однією з властивостей платформ, зважаючи на їхню потребу адаптуватися до мінливих умов. Взаємозв'язок між відкритими цілями та еволюційністю платформи можна побачити на прикладі адаптації партнерств у сфері охорони здоров'я. А. Чідл [4] проводить відмінності між партнерствами, які займаються конкретними питаннями, i партнерствами з узагальненими цілями (на кшталт поліпшення здоров'я нації). Дослідження виявили, що партнерство з більш широкими цілями має тенденцію з часом розширюватися, залучаючи додаткові зацікавлені сторони до розробки нових проєктів, тоді як партнерства, спрямовані на вирішення конкретних проблем, з плином часу звужуються і перетворюються на професійні клуби. Проте, взаємозв' язок між відкритими цілями і можливістю розвитку одночасно $є$ проблемою для подальшого існування платформи. Як зазначає С. Недерлоф, «вельми проблематично спроектувати систему управління, де замість свідомо прогнозованих результатів доводиться постійно змінювати критерії ефективності в процесі налагодження співпраці» [18, с.14].

Колабораційні платформи можуть використовуватися для відтворення спільного управління на різних ієрархічних рівнях або для розширення масштабів співробітництва з плином часу. Підтримка довгострокового співробітництва ускладнюється з появою додаткових спільних проєктів. Чудовим прикладом слугує Водний форум району Сакраменто, де управління водними ресурсами 
супроводжувалося паралельним вирішенням політичних конфліктів між федеральною владою, бізнесом і місцевим соціумом.

Платформи також здатні забезпечити багаторівневе посередництво між локальними спільними проєктами i національними / міжнародними ресурсами. Щоправда, подібне вертикальне посередництво може виявитися складним завданням. Так, І. Деспортес описує політичні та інституційні обмеження, з якими зіткнулася колабораційна платформа в Кейптауні, для вирішення проблеми повеней. Платформа успішно налагодила співпрацю між місцевими жителями, але «не змогла винести проблему повені на порядок денний офіційних осіб і чиновників, які опинилися за межами цільової групи» [7, с.79].

Тому низка платформ спочатку прагнуть вирішити проблему залучення політиків до своїх ініціатив. Наприклад, перш ніж розпочати кампанії боротьби з дитячим ожирінням, платформа EPODE (Ensemble Prévenons l'Obésité Des Enfants) забезпечила високий рівень політичної підтримки по всій країні шляхом мобілізації понад 500 зацікавлених сторін на національному та місцевому рівнях у шести країнах (Франція, Бельгія, Іспанія, Греція, Австралія і Мексика). Тобто колабораційні платформи беруть на себе роль, яку В. Медд і С. Марвін називають «стратегічними посередниками» [15, с.321], розсуваючи межі розподіленої дії, подібно до політичних мереж.

Серед прикладів таких «опорних організацій» варто навести платформу CTC (Coral Triangle Center), програма забезпечення виняткової морської різноманітності на території між Індонезією, Малайзією, Філіппінами, Папуа-Новою Гвінеєю, Східним Тимором і Соломоновими островами. Сформована в результаті співпраці міжнародної екологічної неурядової організації Nature Conservancy і уряду Індонезії, ii діяльність зосереджена на створенні захищених морських районів в окресленому регіоні (MOP). Або платформа East Africa Dairy Development (EADD) виступає в якості платформи сільськогосподарських інновацій з метою просування малого молочного виробництва в Кенії, Танзанії та Уганді. Програма представляє собою консорціум, що складається з Heifer International, Міжнародного науково-дослідного інституту тваринництва (ILRI), Technoserve, African Breeders Services Total Cattle Management Limited i Всесвітнього центру агролісоводства за фінансування Фонду Гейтсів [12]. Платформа об'єднує молочних фермерів і ключових зацікавлених сторін заради розширення ринку молочної продукції в Східній Африці і підвищення рівня життя місцевих фермерів.

У кожному прикладі сприяння співробітництву виступає основним інструментом політики, що використовується для досягнення загальних цілей. I в кожному випадку розподілене співробітництво полегшується, дозволяючи зацікавленим сторонам підключатися до модульних інституціональних інтерфейсів, сконфігурованих з урахуванням локальних потреб і умов.

Низка досліджень доводить, що екосистеми платформ породжуються позитивними зворотними зв'язками або «мережевими ефектами» [11; 15; 20]. Останні часто виникають у результаті колабораційних інновацій, які дозволяють третім сторонам використовувати платформу у власних цілях. 3 метою створення критичної маси зацікавленості, успішні платформи повинні володіти стійкістю до різних комбінацій навичок, знань або інтересів стейкголдерів. У контексті колабораційного управління так званий «ефект атрактора» схиляє зацікавлені сторони вкладати час, енергію і ресурси у співробітництво, яке, за спостереженнями, дає відчутні та успішні результати. Наприклад, Е. Вебер описує еволюцію платформи Blackfoot Challenge, вододільного управління в Монтані, яка з часом ініціювала понад 100 проєктів. За словами дослідника, сам процес взаємодії був побудований на ефекті зворотного позитивного зв'язку, коли «...Blackfoot Challenge, наче магніт, притягувала зацікавлені сторони в уже створену ініціативну групу» [25, с.41].

К. Анселл і Е. Геш [1] ідентифікують кілька ефектів позитивного зворотного зв'язку для колабораційних платформ. По-перше, зацікавлені сторони, які працюють за посередництвом платформи, можуть дізнатися щось нове про природу проблеми, що спонукає до розширення або адаптації спільних зусиль. Гарний приклад такого типу навчання пропонує інституційна адаптація партнерства за естуаріями, описана К. Емерсоном і К. Герлак [8] - Партнерство з естуаріям регіону Піскатаква (PREP). Згодом PREP розширила географічний обсяг, що призвело до появи нових зацікавлених сторін, при цьому тригером подібного масштабування стало визнання обмеженості потенційних варіантів вирішення проблем з огляду на звужену географічну базу.

По-друге, позитивний зворотний зв'язок може виникнути під час пролонгації співпраці між зацікавленими сторонами. Приклад «екологічного моста» від DCDC (Decision Center of Desert City) ілюструють зазначений сценарій. Створення цією організацією «політично нейтрального» простору для спільного навчання зменшило культурні бар’єри на шляху до розширення взаємодії 
між зацікавленими сторонами. Спільне надбання знань за допомогою розробки регіональної моделі водних ресурсів сприяло поліпшенню взаємодії, що, своєю чергою, зміцнило мотивацію до подальшої співпраці.

Л. Томас стверджує, що успішність колабораційних платформ залежить від використання «архітектурних важелів», під якими розуміється «процес створення впливу, непропорційно більшого за початкові передумови» [24, с.206]. Тобто платформа створює мультиплікативний ефект за рахунок розробки загальних активів, дизайну і стандартів, які можна комбінувати, тим самим полегшуючи координацію і управління спільними зусиллями. У своєму дослідженні Дж. Борис також відзначає стратегічну важливість «здатності створювати ефекти соціального мультиплікатора (наприклад, за рахунок залучення зацікавлених сторін у різні формати діалогу і партнерства або ефективних каналів комунікації) і комбінації множинних втручань» [2, с.312].

Проте посередницька роль платформ та їх роль у встановленні правил проєктування для учасників можуть різнитися залежно від переважаючого типу вузлів взаємозалежності. Колабораційні платформи демонструють два типи взаємозалежності: вертикальна (між платформою та іі складовими, себто учасниками, союзниками, постачальниками тощо) і горизонтальна (між самими елементами). Платформи несуть відповідальність за управління обома категоріями.

Так, в умовах горизонтальної взаємозалежності роль посередника полягає в агрегуванні або об'єднанні окремих входів залучення різних складових. 3 посиленням зв'язку між складовими, посередники повинні брати участь в більшій «реляційній роботі» [16, с.1486] для координування їхніх дій. Виходячи з критерію вузлів взаємозалежності, К. Анселл і Е. Геш розрізняють наступні види колабораційних платформ:

Платформи краудсорсингу передбачають об'єднане посередництво та обмежений контроль над розподіленими входами системи за стандартизованого інтерфейсу [1, с.11]. Так, Агентство ООН у справах біженців, UNHCR, створило краудсорсингову платформу під назвою «UNHCR Ideas» 3 метою заохочення відкритих інновацій навколо своєї ініціативи. У процесі пілотного запуску вебпорталу платформа сформулювала наступне завдання: «Яким чином можна поліпшити доступ до інформації та послуг, що надаються UNHCR та партнерами, для біженців і підмандатних людей, які проживають у міських районах?» Веб-сайт дозволив учасникам представити і проголосувати за ідеї шляхом коментарів до онлайн-обговорень. Хоча краудсорсинг може бути більш інтерактивним порівняно з традиційними методами консультацій, взаємодії через краудсорсингову платформу зазвичай не $є$ виявом повноцінного колабораційного управління, оскільки процеси колективного прийняття рішень носять формальний і дорадчий характер.

Платформи знань передбачають сильну вертикальну взаємозалежність між платформами та їх складовими, ніж краудсорсинг. Платформи знань виконують функцію центру обміну інформацією, збираючи відповідні знання від тристоронніх учасників і поширюючи їх серед зацікавлених сторін шляхом зворотного зв'язку [1, с.12]. Міжнародне агентство з атомної енергії (МАГАТЕ), наприклад, сприяє створенню національних платформ знань в галузі ядерної безпеки через формування відповідної віртуальної платформи обміну довідковою інформацією. Такі платформи можуть служити національним, регіональним і глобальним стейкголдерам у якості авторитетного джерела даних, що підтримується безпосередньо державами-членами МАГАТЕ.

Бенчмаркінг-платформи, подібно платформам краудсорсингу і знань, збирають інформацію щодо результативності діяльності національних урядів. Однак компаративні платформи часто створюють вимоги до звітності своїх учасників, надаючи повну інформацію щодо останніх шляхом зворотного зв'язку з метою поліпшення результатів. Організація економічного співробітництва та розвитку (OECD) широко використовувала бенчмаркінг як стратегію заохочення відносно поліпшення національних показників. Бенчмаркінг-платформи «необов'язково $€$ інструментами колабораційного управління» $[1$, c.12], хоча вони мають у своєму розпорядженні чимало елементів співпраці, порівняно з платформами знань або краудсорсингу. Наприклад, концепція «демократичного експерименталізму» С. Сабеля і Дж. Цейтліна [22] поєднує в собі порівняльний аналіз з елементами колаборації.

Окреслені вище приклади колабораційних платформ репрезентують наявність сильних структурованих зв'язків, проте їхня посередницька роль $є$ обмеженою стосовно функції агрегування внесків усіх зацікавлених сторін. У даному контексті мета-мережа відіграє більш широку посередницьку роль без нав'язування єдиних правил проєктування. Вона постає проміжною ланкою між існуючими мережами взаємодії. Так, Світовий соціальний форум створює нейтральний простір для організації антиглобалістських соціальних рухів. Проте, заради уникнення розколу, Форум 
ретельно ухиляється від озвучування єдиної колективної позиції. Такий нейтралітет виступає критичним правилом проєктування зазначеної мережі.

Іншим прикладом слугує мережа співтовариств і Альянсу дій щодо клімату Сполученого Королівства (CСАA). Окреслена мета-мережа сприяє співробітництву між низкою мереж, що працюють над проблемами зміни клімату та енергетики ускладі таких гравців, як Мережа низьковуглецевих спільнот, Транзитна мережа і Мережа кліматичних дій шотландських спільнот. CСАA описує себе як «неформальну групу представників мереж, які підтримують дії на низовому рівні», де «[кожен] член взаємодії бере на себе відповідальність за зв'язок з власною мережею» $[1$, с.13]. Як випливає з цього опису, ССАА представляє собою колабораційну платформу, але ії роль обмежена посередництвом між мережевими компонентами.

Платформи стандартизації або сертифікації створюють чіткі правила проєктування, відіграючи скромну посередницьку роль. Вони встановлюють стандарти, які добровільно приймаються учасниками взаємодії. У деяких випадках ці платформи підтверджують відповідність зацікавлених сторін ухваленим стандартам, покладаючись на сторонніх сертифікаторів. Стандарти і процес сертифікації розуміються як «чітко сформульовані правила проєктування, що визначають алгоритм дій учасників на колабораційній платформі» [1, с.13].

Співпраця може відбуватися двома способами. По-перше, стандарти часто встановлюються в процесі взаємодії. По-друге, зацікавлені сторони повинні брати участь в заявленій колаборації. Наприклад, Морська піклувальна рада (MSC) є інституцією сертифікації розвитку сталого рибальства, що встановлює стандарти, принципи і показники ефективності відповідної галузі. MSC розуміє розроблені стандарти як орієнтири, що відображають передовий міжнародний досвід якісного управління рибальством. Однак MSC виходить за межі добровільної звітності та об'єднання інформації стосовно ефективності імплементації програми, оскільки учасники отримують сертифікат MSC лише в разі їх сертифікації третьою стороною [1, с.14]. Незважаючи на те, що MSC забезпечує технічну та інституційну підтримку промислів, які прагнуть пройти сертифікацію, вона не відіграє пріоритетної ролі посередника під час організації співпраці.

«Опорні» структури, які наводять мости взаєморозуміння, відіграють важливу каталітичну роль у сприянні співпраці, одночасно нав'язуючи мінімальні правила проєктування зацікавленим сторонам. Гарним прикладом платформи-посередника слугує Ecomuseum Kristianstads Vattenrike $(\mathrm{EKV})$, шведська організація, яка об'єднує зусилля зі збереження екологічних і культурних цінностей, пов'язаних з великими водно-болотними угіддями. Організація $\epsilon$ центральним вузлом у більш широкій мережі «проєктів спільного навчання», які заохочуються або ініціюються, проте не адмініструються EKV [11, с.581]. EKV дійсно здійснює певний контроль над цими проєктами шляхом ініціювання певних заходів і відбору учасників. Проте вагома частина енергії EKV витрачається на стратегічне визначення «безпрограшних» стратегій, формування довіри, а також на прив'язку місцевих проєктів до локальних інституцій та спонсорів. Іншими словами, EKV активно бере участь у заходах, але їі роль можна охарактеризувати як посередництво, а не контроль.

Франчайзингові платформи орієнтовані на створення базових структур або технологій колабораційного управління за допомогою механізму відтворення в різних локаціях [1, с.14]. Такі платформи, контролюючи дизайн базового інтерфейсу для колабораційного управління і циклічно повторюючи його, сприяють розширенню масштабів співробітництва. Так, платформа EPODE просуває базову технологію соціального маркетингу, на основі якої організовуються локальні кампанії проти ожиріння; СТС просуває концепцію співпраці навколо основного модуля морського заповідника; EADD відтворює базову концепцію «хаба» в різних фермерських спільнотах.

Функціональні модульні платформи виконують як сильну посередницьку роль, так і суворий контроль проєктування. Модульні компоненти платформ такого типу повинні мати можливість легко взаємодіяти з самою платформою, а згодом працювати як частина функціонального цілого. Така системна функціональність вимагає «суворого контролю конструкції модульних блоків» [1, с.14]. Хрестоматійним прикладом колабораційного управління з таким типом функціональної модульності слугує Каліфорнійська водна спільнота, відома як CALFED. Незважаючи на те, що на зміну їй прийшли нові ініціативи, за час свого існування CALFED створила платформу для співпраці, яка полегшила і скерувала безліч різних спільних проєктів.

Мобілізаційні платформи, або платформи відповідності, орієнтовані на фасилітацію реципрокного обміну між зацікавленими сторонами, хоча їхня посередницька роль за умов вертикальної координації дій $\epsilon$ вельми обмеженою. Наразі платформи відповідності використовуються в якості стратегії управління. Наприклад, Global Hand описує себе як простір 
для узгодження доступних донорських ресурсів з гуманітарними потребами суспільства. Вона управляється міжнародною неурядовою організацією Crossroads Foundation і дійсно виходить за межі вузької ролі в просуванні співробітництва, називаючи себе «...некомерційною брокерською компанією для сприяння державно-приватному партнерству» [19, с.112].

Отже, вузли взаємозалежності між елементами колабораційної платформи у комбінації з їі відмінними властивостями призводять до актуалізації різних сполучень і функцій під час реалізації посередницької функції між глобальними стейкголдерами.

Висновки і перспективи подальших досліджень. Державні агентства, місцеві спільноти, фонди та НУО часто сприймали колабораційне управління як механізм виходу з політичної безвиході i спосіб вирішення локальних проблем. Сьогодні на зміну локально-реактивному баченню приходить усвідомлення колабораційного управління як глобального і проактивного інструменту політики, що може бути використаний в широкому масштабі за допомогою логіки запозичення місцевого контексту і синтезу з національними інтересами.

Крім опису колабораційних платформ як механізмів поглиблення спільного управління, мета статті полягала в розширенні використання концепції платформи за межами IT-сфери та іiі екстраполяції в область державного управління. Платформи мають і демонструють організаційні властивості, які поки що $є$ недостатньо вивченими, але потенційно важливими для розуміння того, як політичний сектор справляється з вимогами збалансувати стабільність системи і необхідність трансформацій. Представляючи собою постійно діючі структури, на основі яких можуть бути побудовані більш гнучкі інституції, платформи можуть бути реорганізовані задля задоволення мінливих потреб. Подібна реконфігурованість посилюється модульністю платформ, що дозволяє «підключати периферійні модулі взаємодії до створеної базової платформи» [24, с. 202] в індивідуальному порядку. Отже, колабораційні платформи призначені для «забезпечення гетерогенних розподілених дій через інтеграцію множинних компонентів» [1, c.15].

Комбінація модульності та високої варіативності дозволяє платформам реагувати на зворотний зв'язок від їх власної діяльності. Ефекти позитивного зворотного зв'язку слугують важливими механізмами еволюції платформи. Маючи в своєму розпорядженні обмежені примусові повноваження щодо учасників колаборації, платформи, проте, здатні координувати дії різних зацікавлених сторін, що має вирішальне значення для успіху потенційного проєкту. Таке стратегічне посередництво колабораційних платформ має здійснюватися з розумінням впливу ефектів атрактора, навчання і синергії.

Звичайно, платформи можуть досягти певного ступеня контролю за допомогою встановлення правил проєктування, що визначають доступ учасників колаборації до спільних ресурсів. Приклади локальних кампаній створення морських заповідників і центрів молочного виробництва свідчать про те, що контроль над дизайном модульних спільних проєктів може стати критичним механізмом у розширенні масштабів співробітництва. Проте посередницька роль деяких платформ у більшості випадків є агрегатною і зводиться лише до об'єднання розподілених внесків зацікавлених сторін. Деякі платформи відіграють більш каталітичну роль у створенні спільних взаємодій між стейкголдерами. Подібна варіативність залежить від цілей колабораційного управління, очікуваних результатів і вузлів взаємозалежності, які безпосередньо впливають на ступінь контролю з боку платформи.

Однією з ключових проблем у дослідженнях колабораційного управління постає встановлення критеріїв результативності, оскільки фінальні очікування корпоративних і державних гравців, а також організацій громадянського суспільства можуть істотно різнитися. Наприклад, С. Марвін [15] пропонує розрізняти прямі і непрямі результати. На його думку, у динамічних коаліціях партнери можуть отримувати або сприймати виключно непрямі вигоди, оскільки прямі ефекти від спільних зусиль стають очевидними лише в довгостроковій перспективі.

Ряд досліджень також показує, що міжсекторальне партнерство може мати неоднозначні результати. Так, стейкголдери екологічних партнерств відзначають зрушення у вирішенні деяких серйозних проблем, тоді як зацікавлені сторони партнерств важкої промисловості побачили появу додаткових ризиків [14; 19]. Однією з причин такого розриву є формулювання цілей колаборації в контрпродуктивному напрямку, що загрожує «зсувом балансу сил у вирішенні питань державної політики» [6, с.190] на користь одного з учасників колаборації.

Концептуальним питанням подальшого вивчення колабораційних платформ виступає алгоритм їх моделювання. Проста модель системи введення-виведення гравців використовується в якості шаблону в більшості досліджень. Такі моделі лежать в основі визначення «функціонально корисних 
вимірювань багатосторонніх партнерств» [5, c.116] i причинних факторів, що впливають на результати спільної діяльності. Хоча подібні моделі, безумовно, корисні для практики та розвитку теорії колабораційного управління, вони, як правило, не враховують вбудованість політикосоціальних процесів у більш великі інституційні структури.

Концепції соціального руху також залишаються в силі, оскільки мінливі очікування суспільства сприяють появі нових викликів і корекції традиційних проблем. Дослідникам слід зосередити увагу на впливі колабораційних платформ відносно стійкості політичних систем, з якою пов'язані завдання багатьох партнерств. Моделі нелінійного виникнення політичних процесів можуть також пролити нове світло на управління стратегічними аспектами платформи, зосередивши увагу на петлях зворотного зв'язку.

Варто відзначити, що більшість академічних робіт, присвячених колабораційному управлінню i платформам, має тенденцію фокусуватися на макро-питаннях, але далеко не всі досліджують мікропроблеми, такі як лідерство, необхідне для галузевих інтерфейсів, або міжкультурні процеси. Тому цінним внеском були б дослідження мікроелементів колабораційних платформ, що стимулюють пролонгування співпраці між зацікавленими сторонами. У зазначеному контексті непогано було б зробити акцент на інституційній динаміці платформи, яка фактично закладає фундамент для ідентифікації та вирішення заявлених проблем.

Таким чином, тематика колабораційних платформ $\epsilon$ перспективною не лише $з$ аспектів поглиблення теоретичного базису таких наукових питань, як державне управління або інтерактивне багатостороннє партнерство, а й з позиції практиків, які прагнуть отримати реальні результати і додаткову легітимацію прийнятих рішень.

\section{Бібліографічний список/References:}

1. Ansell, C., and Gash A. 2017. Collaborative platforms as a governance strategy. Journal of Public Administration Research and Theory:1-17.

2. Borys, J. M., Y. Le Bodo, S. A. Jebb, J. C. Seidell, C. Summerbell, D. Richard, S. De Henauw, et al. 2012. EPODE approach for childhood obesity prevention: Methods, progress and international development. Obesity Reviews 13:299-315.

3. Boudreau, K. 2010. Open platform strategies and innovation: Granting access vs. devolving control. Management Science 56:1849-72

4. Cheadle, A., M. S. Senter, L. Solomon, W. L. Beery, and M. P. M. Schwartz. 2005. A qualitative exploration of alternative strategies for building community health partnerships: Collaboration versus issue-oriented approaches. Journal of Urban Health 82:638-52.

5. Ciborra, C. U. 1996. The platform organization: Recombining strategies, structures, and surprises. Organization Science 7:103-18.

6. Cooke, P. 2007. To construct regional advantage from innovation systems first build policy platforms. European Planning Studies 15:179-94.

7. Desportes, I., J. Waddell, and M. Hordijk. 2016. Improving flood risk governance through multi-stakeholder collaboration: A case study of Sweet Home informal settlement, Cape Town. South African Geographical Journal 98:61-83.

8. Emerson, K., and A. K. Gerlak. 2014. Adaptation in collaborative governance regimes. Environmental management 54:768-81.

9. Emerson, K., and T. Nabatchi. 2015. Collaborative governance regimes. Washington, DC: Georgetown Univ. Press.

10. Furlan, A., A. Cabigiosu, and A. Camuffo. 2014. When the mirror gets misted up: Modularity and technological change. Strategic Management Journal 35:789-807

11. Hahn, T., P. Olsson, C. Folke, and K. Johansson. 2006. Trust-building, knowledge generation and organizational innovations: The role of a bridging organization for adaptive comanagement of a wetland landscape around Kristianstad, Sweden. Human Ecology 34:573-92.

12. Heifer International. 2016. East African Dairy Development. http://www. heifer.org/ending-hunger/ourwork/programs/eadd/index.html (accessed July 13 2016).

13. Janssen, M., and E. Estevez. 2013. Lean government and platform-based governance - Doing more with less. Government Information Quarterly 30:S1-S8.

14. Leach, W. D., C. M. Weible, S. R. Vince, S. N. Siddiki, and J. C. Calanni. 2013. Fostering learning through collaboration: Knowledge acquisition and belief change in marine aquaculture partnerships. Journal of Public Administration Research and Theory 24:591-622.

15. Medd, W., and S. Marvin. 2007. Strategic intermediation: Between regional strategy and local practice. Sustainable Development 15:318-27.

16. Moss, T. 2009. Intermediaries and the governance of sociotechnical networks in transition. Environment and Planning A 41:1480-95. 
17. Nambisan, S. 2009. Platforms for collaboration. Stanford Social Innovation Review 7:44-9.

18. Nederlof, S., M. Wongtschowski, and F. van der Lee. 2011. Putting heads together: agricultural innovation platforms in practice. Bulletin 396, Amsterdam, the Netherlands: KIT Publishers.

19. Ogelsby, R. and J. Burke. 2012. Platforms for private sector-humanitarian collaboration. London, UK: Humanitarian Futures Programme

20. Reid, S., J. P. Hayes, D. Stibbe. 2014. Platforms for partnership: Emerging good practice to systematically engage business as a partner in development. Oxford, UK: The Partnering Initiative.

21. Roth, S., J. Kaivo-Oja, and T. Hirschmann. 2013. Smart regions: Two cases of crowdsourcing for regional development. International Journal of Entrepreneurship and Small Business 20:272-85.

22. Sabel, C. F., and J. Zeitlin. 2010. Experimentalist governance in the European Union: Towards a new architecture. Oxford: Oxford Univ. Press.

23. Selsky, J. W., and Parker, B. 2010. Platforms for cross-sector social partnerships: Prospective sensemaking devices for social benefit. Journal of business ethics 94:21-37.

24. Thomas, L. D., E. Autio, and D. M. Gann. 2014. Architectural leverage: Putting platforms in context. The Academy of Management Perspectives 28:198-219.

25. Weber, E. P. 2012. Unleashing the potential of collaborative governance arrangements: Getting to robust durability in the Blackfoot Valley. Journal of Sustainable Development 5:35.

\section{Sychova A. O. Collaborative Platforms as a Tool of Global Politics}

The article represents an analysis of the category of collaboration platform from the standpoint of the formation of a global political partnership. Collaborative platforms are relatively stable structures to provide a more flexible mode of governance, able to adapt to new opportunities or changing conditions. The author identified the properties of collaborative platforms, namely: flexibility, relative temporal stability, reconfiguration, modularity, and evolution, which allows distinguishing platforms from other tools for facilitating cooperation. The combination of organizational aspects and structural elements of collaborative platforms allows all stakeholders to connect to modular institutional interfaces patterned to local needs and resources. Particular attention was focused on the effects of positive feedback and the synergy of stakeholders' efforts for facilitating coordination and the creation a unique ecosystem of political actors and processes. The article also presents the typology and examples of collaborative platforms depending on the dominant goals of cooperation and interdependence nodes, which indicate the functional variability of platforms in terms of ensuring a joint solution to problem situations. A separate block identified some issues that accompanied the study of collaborative platforms. Among them, special attention was paid to the contradictions of the effective cooperation criteria, the degree of a potential control, and the problems of intersectoral partnership. The author also outlines the prospects for further study of collaborative platforms as mechanisms of adaptive governance, namely: taking into account the elements of cooperation and institutional dynamics of platforms, determining algorithms for modeling, and the impact of platforms on the stability of the political system as a whole.

Keywords: collaborative platform, collaboration, collaborative governance, partnership, mediation 